\title{
Leo Lowenthal
}

\section{Litteratursociologi - et tilbageblik}

I mere end et halvt århundrede har jeg især beskæftiget mig med litteratursociologi og med massekulturens problemer. Med økonomisk støtte fra Institut for Socialforskning ved Frankfurt Universitet påbegyndte jeg i 1926 studiet af tyske forfattere i 1800-tallet.' I disse studier kan man måske spore den samfundskritiske ånd, der fik denne gruppe af unge forskere ved instituttet til at forkaste konventionelle forskningsmetoder og til at søge nye og dristigere veje $i$ analysen af samfunds- og humanvidenskabernes emneområder - kort sagt dens mod til at søge uden for det akademiske elfenbenstårn, hvor specialister lod sig lede af deres faglige interesser uden nogen som helst samfundsmæssig eller moralsk bevidsthed. Jeg nød det privilegium at være et af de forste medlemmer af denne gruppe, som jeg tilsluttede mig i 1926 på opfordring af Max Horkheimer og Friedrich Pollock.

De år, jeg var under uddannelse, helligede jeg mig studier i sociologi og litteratur. Senere, i mit første selvstændige arbejde, søgte jeg at anvende det, jeg havde lært af Marx, Freud og den store europæiske, filosofiske tradition, med henblik på en nytolkning af europæisk litteratur fra renæssancen og frem. Som mange andre intellektuelle i mine kredse var jeg dengang overbevist om de vestlige samfunds forfald. Vi oplevede alle Hitlers fremmarch som en trussel og betragtede den som et udtryk for, at resten af den såkaldt civiliserede verden var præget af forfaldet. Hver af os søgte, ud fra sin egen viden og sit eget interessefelt, at fortolke historiske og samtidige problemer på en sådan måde, at vi kunne afsløre deres samfundsmæssigt regressive eller progressive karakter. $\mathrm{Vi}$ forkastede forestillingen om wværdifri videnskab« som en utilgivelig afvisning af det moralske ansvar, der påhvilede $\mathrm{dem}$, som - i skarp kontrast til gennemsnitsbefolkningens elendige situation - havde den nådige skæbne at leve en tilværelse som intellektuelle. Hvis nogle af formuleringerne i det følgende forekommer partiske eller ligefrem vrede, vil jeg ikke bede om undskyldning herfor. Tværtimod ville sådanne beskyldninger glæde mig. Der var grund nok til vrede - i det videnskabelige virke som i det offentlige liv. 
Fra min skoletid har jeg været draget mod litteraturen, og det er bestemt ikke noget tilfælde, at jeg i adskillige år arbejdede som tysklærer ved et gymnasium i Frankfurt, inden jeg blev knyttet til instituttet. Jeg har en mistanke om, at jeg fra begyndelsen nærede en forkærlighed for litteraturkritik, for som ældre studerende og ung lærer havde jeg oplevet, hvor utroligt banalt litteraturundervisningen blev grebet an af de fleste undervisere, ganske i overensstemmelse med de officielt godkendte fagbøger. Først og fremmest var jeg imidlertid irriteret over det totalt konventionelle valg af litterære tekster. Eftersom jeg i årene efter Første Verdenskrig levede som en politisk radi$\mathrm{kal}$, omend ikke ligefrem rabiat revolutionær, ung mand, forekom det mig helt naturligt, at jeg udnyttede mine praktiske erfaringer fra undervisningen og det politiske liv i mit teoretiske arbejde ved instituttet.

Jeg opdagede snart, at jeg var helt isoleret i mine forsøg på at bedrive litteratursociologisk forskning. Man søgte i det hele taget næsten forgæves efter fagfæller, hvis man ønskede at nærme sig en litterær tekst ud fra en kritisk samfundsteori. Der var ganske vist Franz Mehrings artikler, som jeg læste med interesse og udbytte; men trods forfatterens beundringsværdige hæderlighed og kompromisløse politiske radikalisme, overskred han næppe grænsen for den socialistiske journalistik. Han skrev fundamentalt på samme måde om litteratur som om politik og økonomi. Georg Lukács havde endnu ikke offentliggjort sin væsentlige række af værker om marxistisk æstetik og litteraturfortolkning. Naturligvis blev jeg dybt berørt og påvirket af hans glimrende lille bog Romanens Teori (1920), som jeg næsten kunne udenad. Udover Levin Schückings lille værk om den litterære smags sociologi, var den eneste anden store påvirkning, jeg kan erindre, Georg Brandes' monumentale værk om hovedstrømninger i det 19. århundrede.

Ikke desto mindre var jeg modig, for ikke at sige overmodig, nok til at planlægge en ambitiøs række af samfundskritiske værker om fransk, engelsk, spansk og tysk litteratur, som skulle tage udgangspunkt i de ovennævnte studier. Min opmærksomhed rettede sig især mod forfattere og litterære skoler, som den etablerede tyske kritik enten straffede med total fortielse (for eksempel "Det unge Tyskland« og Friedrich Spielhagen) eller hævede op i en tåge af idealistisk sniksnak (Goethe og romantikerne) eller degraderede til halv-folkloristisk antropologi (C. F. Meyer og Gottfried Keller).

I disse studier begrænsede jeg mig til narrative former for litteratur. Af grunde, som jeg mener er samfundsmæssigt og kunstnerisk holdbare, er det min opfattelse, at romaner og fortællinger udgør den 
væsentligste litteratur i 1800-tallets Tyskland. Skønt jeg ingenlunde skammer mig over disse værker fra min ungdom, kan jeg se deres svagheder. Hvis jeg skulle skrive dem igen, ville jeg afgjort være mindre hăndfast $\mathrm{i}$ etableringen af de forbindelser, jeg trak mellem litteratur og forfattere på den ene side, og den samfundsmæssige infrastruktur på den anden. I senere udgivelser prøvede jeg at analysere formidlingen mellem basis og overbygning, mellem sociale bevægelser og ideologier med større varsomhed; men mit syn på den samfundsmæssige verden og min tro på nødvendigheden af at forene samfundsteori og litterær analyse har ikke ændret sig på nogen fundamental måde. Gennem de sidste årtier er litteratursociologi efterhånden blevet mere af en modesag. Mine samtidiges skriverier har tit forbløffet mig, fordi nogle - ofte i et unødigt kompliceret og esoterisk sprog - er så optaget af »formidlingsformer«, at forbindelserne mellem social væren og social bevidsthed næsten udviskes.

Det første nummer af Zeitschrift für Sozialforschung - det eneste vi nåede at udgive $\mathrm{i}$ Tyskland, inden Hitler-natten sænkede sig - giver et begreb om, hvad Kritisk Teori betyder: nemlig et perspektiv, baseret på en fælles kritisk grundholdning, som anlægges på alle kulturfænomener uden nogen sinde at gøre krav på at være et system. Den omfatter kritisk analyse af filosofi, økonomi, posykologi, musik og litteratur.

Kritisk Teori - et begreb vi i øvrigt først begyndte at anvende hen imod 30'rnes slutning - bør således ikke forstås som andet og mere end denne kollektive »fællesnævner«. Som den eneste overlevende fra de første år i 20'rne, føler jeg mig næsten ubehageligt til mode... Hvorfor skulle jeg overleve og ikke de andre, som i 1926 indbød mig til at deltage $i$ et intellektuelt fællesskab, som de havde skabt $\mathrm{i}$ institutionaliseret form to år tidligere? Vi talte ikke om »Kritisk Teori« på det tidspunkt, og tanken om en »skole« var os helt fremmed. Vi var og forblev »nej-sigere« $\mathrm{i}$ traditionen fra Hegels særlige form for negation; hver af os prøvede at formulere, hvad der var galt fat inden for hans specielle område og dermed også i vort samfund. Vi placerede os bevidst i periferien af den etablerede magt. Som det vil fremgå, betragter jeg endnu i dag denne placering i periferien, denne marginalitet, som den vigtigste kategori for mig, i mit arbejde, måske endda i min egen opfattelse af livet. Gennem de sidste 50 år har ledetrå- 
den i mit arbejde været en ubrudt beskæftigelse med den europæiske litterære arv, sideløbende med en kritik af den vare- og ord-produktion, som finder sted i et manipuleret og manipulérbart massemarked. Jeg skal prøve at skitsere min kritiske fremgangsmåde.

For nu at lægge ud med det allervigtigste: Kunst og forbrugsgoder bør holdes skarpt adskilte, og jeg kan ikke bifalde nogen af de nutidige bestræbelser - i radikale kredse både i Europa og USA - på at udviske dette skel. Ganske vist kan forbruget af ægte kunst også gøres til massekultur og spille en rolle i manipuleringen af samfundet. Lad mig blot minde om Wagners rolle i Hitler-årene, som Theodor Adorno har skrevet udførligt om. Mere besynderlige eksempler kan f.eks. findes i teaterinstruktionens historie, når borgerlig snusfornuft trivialiserer ægteskabets og kærlighedens iboende tragik. Her tænker jeg i.eks. på en engelsk opførelse af Othello i 1700-tallet, hvor Moren ikke dræber Desdemona i den sidste scene, men indser sin egen fejl og beder hende om tilgivelse, så at de kan leve lykkeligt sidenhen; eller på en München-opsætning omkring århundredeskiftet af Ibsens $E t$ Dukkehjem, hvor Nora ved stykkets slutning ikke lukker døren udefra, men indefra, og går tilbage til sin kedsommelige mand - for kvindens plads er trods alt i hjemmet. Disse eksempler afspejler tydeligt det sociale klima. På den anden side findes der visse værker, oprindeligt produceret som forbrugsartikler, der opsuges i folkekunsten eller rettere i den folkloristiske mytologi, men de er sjældne grænsetilfælde. Jeg må også pointere, at der eksisterer visse forskelle på forholdene $\mathrm{i}$ USA og Europa. I USA er litteratursociologi noget, der ret snævert knytter sig til indholdsanalyse af massekultur og studiet af massekulturens virkninger med særlig vægt på kommerciel og politisk propaganda. Den model, der anvendes i disse studier, er behavioristisk - og det vil sige ahistorisk. Litteratursociologi i betydningen analyse af kunst er stadig suspekt. I Europa eksisterer der i dag, føler jeg, en tilbøjelighed til at opfatte et kunstværk som en manifestation af en ideologi slet og ret. Dermed berøves det sin særlige integritet, sin historisk betingede, men også rationelt skabende og erkendelsefrembringende rolle. Eller for at sige det mere provokerende: Den marxistiske litteraturforskning er ikke blot fuldstændig adækvat ved analysen af massekultur, den er også uomgængelig. Over for kunsten selv må den imidlertid anvendes med den yderste forsigtighed, og den må, 
som en kritik af samfundsmæssige illusioner, begrænse sig til de restfænomener, der er utvetydigt ideologiske af natur.

Sagt endnu stærkere: Kunsten belærer, massekulturen indoktrinerer. Det betyder, at den sociologiske kunstanalyse må være varsom, supplerende og selektiv, mens en sociologisk analyse af massekultur må være altomfattende, for massekulturens produkter er udtryk for og symptomer på de processer, der befordrer individets selvresignation $i$ et fuldstændigt forvaltet samfund.

Jeg vil nu gå over til at tale om kunstværkets litteratursociologi. Adorno har engang sagt: »Kunstværker besidder kun storhed, for så vidt de lader det tale, som ideologien fortier. De overskrider, om de så vil det eller ej, den falske bevidsthed." Litteratur er ikke ideologi; vi beskæftiger os ikke med forskning i ideologi - i stedet retter vi vor opmærksomhed mod den særlige sandhed, det specifikt erkendelsesmæssige aspekt, det litterære værk videregiver. Denne opmærksomhed bringer os ikke i selskab med nogen variant af »ny-kritikken «, tværtimod indebærer den beskæftigelse med kunstens social- og virkningshistorie, sådan som det skitseres i Marx' bemærkninger om den græske tragedie og Balzac's romaner. Her ville jeg godt pege på de store temaer i litteraturen, som jeg opfatter dem fra et sociologisk, kritisk perspektiv. Først det mest generelle. Litteraturen er den eneste pålidelige kilde til den menneskelige bevidsthed og selvbevidsthed, til individets erfarede forhold til sin verden. Socialiseringsprocessen, den sociale resonansbund for det private, det intime og det individuelle, hæves til bevidsthed af kunstneren i hans egen tid, men føres tillige videre $\mathrm{i}$ vor tid og fungerer derved som et stadigt korrektiv til vor falske bevidsthed. Opmærksomhed om denne side af kunsten er forst blevet et vigtigt tema i den intellektuelle debat gennem de sidste 50 år, da den vestlige verden kom i alvorlig krise med totalitarismens opkomst. Kunstsociologien er i sandhed en af Minervas ugler. Litteratursociologi i egentlig forstand bør fortolke det, der synes fjernest placeret i forhold til samfundet, som den gyldigste nøgle til forståelse af samfundet og især af dets problemer. I øvrigt er psykoanalysen, som afslører den samfundsmæssige dimension af kroppens og psykens mest intime sider, et mønstereksempel på det, jeg sigter til. Særlig vigtig er for mig den kritiske litteratursociologis rolle i analysen af det intimes og privates sociale resonansrum, afdækningen af den sam- 
fundsmæssige betingethed bag fænomener som kærlighed, venskab, forholdet til naturen, selvfremstilling og lignende. Dette er ikke ensbetydende med reduktionisme. Litteratur er ikke et kildemateriale slet og ret. Jeg afviser alle forsøg på at betragte litteraturen som et redskab til erhvervelse af data og facts om institutioner som økonomien, staten og retssystemet. Det skulle forbydes samfundsforskere og socialhistorikere at betragte litteraturen som en kilde til råmaterialer. Det, litteraturen lærer os at forstå, er, hvorledes individernes socialisering lykkes eller mislykkes under konkrete historiske betingelser, i konkrete perioder. Stendhals romaner, f.eks., og især Lucien Leuwen, ville være en fremragende kilde til studiet af, hvorledes erfaringsformerne ændres, fra en feudal til en aristokratisk til en borgerlig individtype.

Hvis man finder det, jeg hidtil har sagt, for formalistisk, så må det kritiske perspektiv endnu engang accentueres. Når jeg omtaler historien om individets socialisering, taler jeg samtidig om dets lidelsers såvel som dets lidenskabers historie. Den litteratur, jeg er fortrolig med, nemlig vesteuropæisk litteratur siden 1600-tallet, er historien om menneskelige lidenskaber under en stadigt eksisterende krise, den lange, bitre beretning om spændinger, løfter, forræderi og død. Det borgerlige samfunds litteratur synliggør individets permanente krise. Om litteratur er kunst afgøres af, om og i hvilket omfang den fremstiller krisen som permanent. Og dermed er vi ude på randeksistensens, marginalitetens, risikofyldte område.

Den mest yderliggående form for randeksistens, nemlig den bevidste eller ubevidste kritik af samfundet, formuleres med styrke af de personer, der ved, at humanitetens dødsdom allerede er beseglet, inden vi når vores sociale tilværelses såkaldte blomstringsperiode. Stendhal lader i Rødt og Sort en af de figurer, han identificerer sig med, udtale: »Det eneste, jeg kan se, der kendetegner et rigtigt menneske, er en dødsdom... Alt andet er til købs. «Og et halvt århundrede senere udtaler Walter Pater i sin Renaissance: Studies in Art and Poetry følgende:

Godt! Vi er alle condamné, som Victor Hugo siger: vi er alle underlagt en dødsdom, som er udsat på ubestemt tid - les hommes sont tous condamné à mort avec des sursis indéfinis: vi er tildelt et interval, og derpå forsvinder vi ud i ukendtheden. Nogle tilbringer dette interval i sløvhed, nogle i lidenskabelig bevægelse, de klogeste, i det mindste blandt »denne verdens børn «, lever det i kunst og sang. ${ }^{2}$

Dette betyder, i nyromantikerens sprog, at kun kunsten kan kommunikere det sandt gode i menneskeliv og erfaring, et løfte om lykke, som forbliver uopfyldt. 
Hermed er jeg nået til det der først og fremmest kendetegner marginaliteten, nemlig kunstnerens egen sociale placering. Hans syn på verden er skævt, men fra sin skæve vinkel ser han den, som den er, nemlig fordrejet. Kunstneren er ikke nogen cartesianer, men en dialektiker, der retter sin opmærksomhed mod det idiosynkratiske, det der ikke passer ind i systemet. Det er kort sagt de menneskelige omkostninger, der optager ham, og derved gør han fælles sag med Kritisk Teori, med det kritiske perspektiv, der selv er en del af en kritisk praksis.

Kunstværkets marginalitet repræsenteres af grupper, situationer og protagonister. For det første ser Kritisk Teori den litterære kunstner som sin forbundsfælle, når han er talsmand for kollektivet af udstod$t e$ : de fattige, tiggerne, forbryderne, de sindssyge, kort sagt alle dem, der bærer samfundets byrde. Her finder man imidlertid kunstens sande dialektik manifesteret på en måde, som - i overensstemmelse med Adornos ovennævnte bemærkning - gør det meningsløst at tolke den som ideologi slet og ret. I forfatterens genskabelse, der kommer virkeligheden nærmere, end den ubearbejdede virkelighed selv gør, vises det, hvorledes kollektivet af de profit-og privilegieløse legemliggør menneskets første natur. I de elendiges kollektivitet afsløres muligheden for sand menneskelighed ikke som en forvrængning, men som en iboende anklage. Der ligger en dialektisk ironi i dette, at de, der mindst passer til en triviel, borgerligt-ideologisk forestilling om individet, er dem, der bærer en frigjort, autonom menneskeligheds mærke.

Må jeg her tillade mig at referere til min analyse af Cervantes' værker som eksempel på skildringen af socialt marginaliserede grupper:

"Der er to komplementære måder, hvorpå man kan betragte Cervantes' outsider-figurer: de er udskud i det samfund, der har forstødt dem, og de er, med selve deres eksempel, moralister.

Alle disse marginaliserede skikkelser, tiggerne, svindlerne, sigøjnerne, de sindssyge, er affald fra det samfund, de enten ikke ønsker at tilhøre, eller med vold er udstødt af. Men samtidig med at de anklages, dømmes og spærres inde, er de selv på deres side anklagere. Med selve deres eksistens forkaster de en verden, de aldrig har skabt, og som ikke vil vide af dem. Ved at give disse mennesker stemme søger kunstneren måske at skabe ubehag hos dem, der lukrerer på den herskende orden. Forfatterens stemme er tabernes stemme. Denne anden måde at betragte de udstødte på fører os tilbage til begrebet om det utopiske. De udstødte har ikke kun den negative funktion at rette anklage mod samfundsordenen; de viser også positivt, hvad der 
er menneskets sande bestemmelse. Alle tjener de til at vise frem mod et utopisk samfund, hvor enhver har ret til afvige, som han lyster med det resultat, at selve fænomenet afvigelse forsvinder. Udskudssamfundet af røvere og tyve, som udøver deres erhverv i udkanten af Sevilla, og sigøjner-samfundet i sin lejr uden for Madrid, er groteske prototyper på et utopisk samfund: enhver arbejder i overensstemmelse med sit talent, og alle er fælles om alt.

Meningen med Cervantes' kritiske idealisme træder endnu klarere frem i Den lille Sigøjner. Gruppens overhoved siger: »Vi overholder strengt venskabets lov; ingen mand kaster længselsfulde blikke efter en anden mands kvinde; vi lever frigjort fra skinsygens bitre forbandelse.«På tærskelen til det nye samfund beskriver Cervantes den lov, der styrer det, og konfronterer det med dets erklærede målestok: det autonome og moralsk ansvarlige individ. Og dette ansvarlige og uafhængige menneske findes kun i udkanten af det samfund, der på én gang frembringer og udstøder det. ${ }^{3}$

Et kritisk perspektiv på de marginalgrupper, der portrætteres i litteraturen, må især fremdrage kvindens placering som det mest radikale eksempel. Lige siden renæssancen har forfatteren ladet kvindeskikkelser være de sandt revolutionære kritikere af samfundets mangler. Ibsen sagde engang: "Det moderne samfund er ikke et menneskesamfund; det er kun et mandssamfund. « Denne diskriminering af kvinder har imidlertid ikke kun negative, men også positive konsekvenser.

Ibsens mænd gør aldrig selv, som de præker, og det eneste princip, de selv folger - den personlige vindings materialistiske princip vedkender de sig aldrig. Også kvinderne er materialistiske, men deres materialisme er af en helt anden art, og først og fremmest formuleres den åbent. Der er en bevidst dramatisk ironi i dette, at moral prækes af egoisterne, mens egoisme prækes af moralens bærere.

For det andet er situations-marginaliteten og gruppemarginaliteten tæt forbundet med hinanden. Vigtige eksempler kan man finde $\mathrm{i}$ Shakespeares stykker, især i Stormen, i Kong Lear og i Timon of Athens, hvor personerne drives ud i den civilisationsløse naturs vildmark. Her opfattes naturen ikke som et råmateriale, der kan misbruges og udnyttes af et klassesamfunds magtbegær - en udbytning der svarer til den, de allerede omtalte udstødte grupper udsættes for. Når naturen i disse stykker udtrykkeligt fremstăr som de utæmmede elementer, bebuder det samtidig en forsoning af menneske og natur. Den oprørte natur gør fælles sag med det oprørte menneske for at dømme et ondt samfund. I Stormen udtrykkes dette tydeligt, når den ubundne natur fører menneskets anden natur, dets tingsliggjorte og samfunds- 
skabte maske, tilbage til hans sande natur. Den absolutte fattigdoms marginalisering (ikke at forveksle med Robinson Crusoes situation), som til at begynde med rammer Prospero, Lear og Timon, udvikler sig efterhånden til at blive en velsignelse, og dermed til en foregribelse af utopien. Utopien (vil jeg påstå med al mulig styrke uden at kunne føre bevis), utopien forstået som forsoningen af menneskets forste natur og naturen, er - skjult eller åbenlyst - det fundamentale tema $\mathrm{i}$ al autentisk littertur.

For det tredje: når protagonisten selv optræder som en marginaliseret figur, er syntesen mellem marginalgrupper og marginalsituationer skabt eller i det mindste foregrebet, lige fra Rabelais' Pantagruel til f.eks. Günter Grass' Bliktrommen og helt op til allernyeste tid. I disse værker er der ingen som helst lighed mellem klassesamfundets gennemsnitsindivid og protagonisten. Don Quixote er symbolet på en kritik af det borgerlige samfund og dets fremmanipulerede konformisme, i dets senfeudale skikkelse omkring år $1600 \mathrm{og}$ frem til nutiden. Han er det ahistoriske symbol på en æg te historisk materialisme. Når han optræder tosset, er han ved sine fulde fem; når han agerer irrationelt, er han i virkcligheden rationel. Han er den eneste, der virkelig er lykkelig, næsten salig - just fordi han betragter samfundet fra sin skæve kritiske vinkel og "retter det ud « med sine fantastiske gerninger. Han fører sin kritiske idealisme ud i praksis, og derved repræsenterer han alle individers udfoldelse af deres muligheder. Skønt han ødelægges og til sidst dør, legemliggør han stadig en foregribelse af alt det, livet kunne være. Hans fantasier rækker frem mod det, der forbliver usynligt i denne beskadigede verden. Eller for at citere Hegel:

I (Cervantes') Don Quixote drejer det sig om en ædel natur, hos hvem ridderidealet bliver til forrykthed, idet hans eventyrlige oplevelser sættes ind i en fast, velafgrænset tilstand, hvis ydre træk er formet efter en nøjagtigt skildret virkelighed... Don Quixote er, med al den forrykthed, der kendetegner ham og hans sag, et fuldstændigt sikkert gemyt, eller snarere består forryktheden kun deri, at han er og bliver så sikker på sig selv og sin sag. ${ }^{4}$

Kort sagt: i ham, gennem ham, virkeliggøres sammenfaldet mellem teori og praksis.

Inden jeg kort vil omtale massekulturens problemfelt, vil jeg som overledning endnu engang henvise til Stendhal, som efter min mening mesterligt analyserer de erfaringer, der er forbundet med socialiseringsprocessen. Han foregriber, rigtignok på en nu forældet måde, et samfundsklima, hvor konformismen totalt overdøver den ægte erfaring. Det er just massekulturens vigtigste kendetegn. Når Lucien, i 
Lucien Leuwen, hverken kan udholde det dekadente restaurationssamfund eller den nye borgerlige verdens juste-milieu, sysler han - som helten i Wilhelm Meisters Vandreår med ideen om at udvandre til Amerika. Citatet taler for sig selv:

\footnotetext{
Lucien havde følt en sådan trøstesløshed, siden han kom til Nancy, at han i mangel af bedre lod sig opsluge af denne republikanske skrivelse. "Det bedste for dem alle ville være at sejle til Amerika... Skulle jeg sejle med dem... Helt så tosset er jeg ikke... Jeg ville kede mig i Amerika midt iblandt mennesker, som rigtignok er absolut ærlige og fornuftige, men grove, og som ikke tænker på andet end dollars. $\varsigma^{5}$
}

Kedsomhed er nøgleordet; det er den oplevelsesmåde, 1800-tallets kunstnere giver udtryk for ud fra det samme perspektiv som Kritisk Teori, stillet over for det moderne livs frembrydende manifestationsformer.

\section{4}

Mine egne analyser af massekultur benytter termen »kedsomhed «, fordi den peger på den væesentligste faktor: den forkrøbling af fantasien, som hæmmer kunstnerisk erfaring og giver manipulationens kræfter frit spil. Et par eksempler kan belyse, i hvilket omfang »forvaltningen«, d.v.s. undertrykkelsen, af fantasien er en del af massekulturindustrien. I USA, som i Tyskland, er bogklubber big business. Et firma, der hedder Time Books, bebuder et »læseprogram«. Mod en beskeden sum lover programmets ophavsmænd os tre-fire bøger om måneden og opfordrer os til at deltage i en »tilrettelagt læseoplevelse « med garanti for, at »du vil kunne læse bredt og udbytterigt, selv om din tid er begrænset... I stil og indhold er disse mange bøger tidløse. 《Udvalgets pålidelighed er hævet over al tvivl: »Programmets styrke ligger $i$, at udgiverne har brugt tusinder af timer for at finde svar på de spørgsmål, som også du må have stillet dig mange gange... Det er en del af deres job at udvælge de få bøger, der hæver sig skyhøjt over alle andre." Vi forsikres om bøgernes væsentlighed, kvalitet og relevans: „I hvert enkelt tilfælde vil udgiverne skrive særlige introduktioner, som understreger, hvad der er enestående ved bogen, hvilken indflydelse den har haft eller vil fă, hvilken plads den indtager i litteraturen og i samtidens tænkning. « Oven i alt dette kommer indbindingen, der giver projektet en art religiøs nimbus: »Bøgerne er indbundet $i$ holdbare, smidige bind, magen til dem der anvendes ved indbinding af kostbare bibler og messebøger.« 
Et andet eksempel: The Literary Guild, en af de mest succesrige amerikanske bogklubber, lancerede for nylig en billig særudgave af Anna Karenina, Madame Bovary og Dumas' Camille. Annoncens ord lød:

\footnotetext{
Disse tre klassiske romaner, som nu udgives samlet i en smukt indbundet serie, fortæller historien om en trio af tragiske og uforglemmelige kvinder, som satte deres liv ind på kærligheden og derved mistede alt. Tolstojs Anna Karenina, som vender sit aristokratiske miljø ryggen for at folge sin kærligheds stemme, Dumas' Camille, som yder de største ofre for den mand, hun elsker, og Flauberts Madame Bovary, en blid drømmerske, hvis romantiske længsel fører til voldsomme handlinger.
}

Disse eksempler viser, hvorledes massekulturen degraderer kunst til forbrugsartikler. Kærlighedens sejre og nederlag, som de opleves af Fausts Gretchen eller Anna Karina, er, når det kommer til stykket, ikke eviggyldige udsagn om kvindens natur, men må ses som specifikke tolkninger af kvinders situation under bestemte forhold. Det ville ikke være et nær så groft udtryk for massekulturens manipulatoriske overgreb, hvis eksperterne, i stedet for at kaste sådanne bøger billigt ud på massemarkedet, havde erklæret, at disse kvinder alle er neurotiske og afgjort ville klare sig bedre i dag efter en psykoanalytisk behandling! Kort sagt, organiseringen og »forvaltningen« af fantasien er overtaget af sociale kontrolorganer. Dette markeds produkter er legitime genstandsområder for adfærdsvidenskaberne; i denne sammenhæng er reduktionismen i sandhed en adækvat model.

Massekulturen udtrykker og forstærker de forskrifter i det senkapitalistiske samfund, som fremtvinger et falsk fællesskab. I den forstand har jeg altid betragtet mine studier som politiske. Især to eksempler falder mig ind, som forekommer mig symptomatiske for den ødelagte borgerlige selvbevidsthed og for den gennemgribende mentale afmagt, der præger brede dele af mellemlagene. Det ene eksempel har med genre, det andet med reception af litteratur at gøre. De to fænomener er tæt forbundet.

Et af mine arbejder havde som emne modtagelsen af Dostojevskij i Tyskland ved århundredeskiftet, som den er dokumenteret i et omfattende antal bøger såvel som i artikler, tidsskrifter og aviser. Det stod mig snart klart, at den voldsomme interesse for Dostojevskijs værker ikke nødvendigvis var en følge af deres æstetiske kvalitet, men snarere af dybere socialpsykologiske behov. Dostojevskij var - med Goethe som mulig undtagelse - dén litterære figur, der blev skrevet mest om på det tidspunkt. Analysen af materialet viste, at modtagelsen af Dostojevskijs værker afslørede de væsentlige idiosynkrasier i en tid præget af total krise for det tyske samfund: forgabelsen i kunstnerens såkald te irrationalisme; det påståede mysterium i individets liv; en 
svælgen i »sjælens natsider«; glorificeringen af forbryderens adfærd - kort sagt uundværlige elementer af det, der siden indoptoges $\mathrm{i}$ nationalsocialismens psykologiske sublimering af volden.

At receptionsundersøgelser kan have socio-politisk signifikans så jeg bekræftet adskillige år efter, da jeg kiggede nærmere på anmeldelser af den forfatter, som jeg - år før det blev åbenbart - havde anset for nazi-sympatisør, nemlig Knut Hamsun. Historien om modtagelsen af Hamsuns værk kan afspejle udviklingen i politisk bevidsthed fra liberalisme til den autoritære stats paroler. Den borgerlige litteraturkritik overraskede ikke nær så meget som de socialdemokratiske reaktioner. Hvis man læser de kommentarer om Hamsun, der offentliggjordes i det tyske socialdemokratis førende teoretiske tidsskrift, Die Neue Zeit, finder man i 90'erne en klar politisk markering: Hamsuns romaner bør forkastes, de fremstiller ikke levende mennesker, men snarere uklare holdninger, der intet har at gøre med positivt samfundsforandrende bevægelser.

Hvis man imidlertid kigger på udgaver af Die Neue Zeit fra begyndelsen af Første Verdenskrig og årene umiddelbart efter krigen, finder man lovprisninger af den samme forfatter, som tyve år tidligere var blevet så entydigt affærdiget. Det, der førhen var blevet fordømt som »tom atmosfære" og "ren nervepirring «, blev nu opfattet som "gribende skildringer af livet og sjælen, hvori den mest livagtige virkelighed med al dens lys og skygge hæver sig til sindbilledlig tolkning af livets dybder «. Den forfatter, der havde forekommet de tidligere kritikere at være »et formløst udråbstegn i en melankolsk lænestol«, var nu vokset til »ensom storhed «, og han kunne ikke sammenlignes med andre uden vanhelligelse af geniet. Hans romaner havde tidligere været »så flygtige som atmosfæren«, nu var de pludselig blevet »en parabel over det evige«.

Efter Første Verdenskrig istemtes lovsangen både af borgerskabets liberale talsmænd og af repræsentanter for det proletariat, som Hamsun sådan foragtede. Den konventionelle borgerlige kritik og den socialdemokratiske i Die Neue Zeit indgik i samme konstellation: en politisk resignation, en længsel efter ideologisk forførelse, som trivedes i brede sociale grupperinger i Centraleuropa.

Mine genre-studier undersøgte den biografiske mode. Jeg prøvede at analysere den populære biografi i to forskellige samfund for at se den som udtryk for væsentlige ændringer i den politiske og samfundsmæssige struktur. Det første studie nåede jeg at gennemføre i Tyskland, før 1933. I dag kan man næppe forestille sig den syndflod af populærbiografier, der oversvømmede Europa og Tyskland. Allerede i 1918 var populærbiografien det klassiske eksempel på eskapist-litte- 
ratur for det tyske borgerskab. Biografien både fortsætter romangenren og vender den på hovedet. I den borgerlige roman fungerer dokumentationsarbejdet som råmateriale. Det stik modsatte gælder populærbiografien, Her overtager de forskellige former for dokumentation, hele overflødighedshornet af hårde data, begivenheder, navne, breve o.s.v., de sociale relationers plads og bliver individets lænker. Individet er så at sige ikke andet end et typografisk element, en spalteoverskrift på rejse gennem bogens begivenhedsforløb, en undskyldning, slet $o g$ ret, for et smagfuldt arrangement af en bestemt materialesamling. Populærbiografiens helte har ikke nogen individuel skæbne, de er kun funktioner af det historiske. En relativisme, der sjaldent er denne litteraturs udtrykkelige credo, lurer overalt. De stores bevidste kynisme er totalt fraværende, hvad der er tilbage er behovet for at tilsløre tabernes hjælpeløshed. 90'ernes, fin-de-siècle-periodens, æstetik er indbegrebet af handlingsudfoldelse i sammenligning med den lammelse og svaghed, der udgår fra disse populærbiografier. I disse vidnesbyrd om de dødeliges udødelighed, i denne labyrint af superlativer $o g$ proklamationer om det enestående, som fornuften aldrig kan gøre sig håb om at vise os vej gennem, er forfatterne mindst lige så fortabte som deres læsere.

Populærbiografier i USA fungerede i en anden samfundsmæssig sammenhæng. Hvad jeg prøvede at vise i min undersøgelse af masseidolernes triumf $i$ adskillige vidtudbredte amerikanske ugeblade var en strukturel forandring $i$ behandlingen af populærbiografier i overgangsperioden fra den liberale kapitalisme til den manipulerede kollektivisme. Jeg betegnede det som ændringen fra produktionens idoler til konsumtionens idoler. Mens de såkaldte helte omkring århundredeskiftet repræsenterede produktionslivet, blev disse "helte $\mathrm{i}$ slutningen af 30'rne og begyndelsen af 40'rne i stigende grad erstattet af sportsfolk og folk fra underholdningsbranchen, især fra filmen, og det, der tilsyneladende gav dem »nyhedsværdi«, var deres privatliv snarere end deres arbejdsfunktioner. Den identifikation, læseren blev tilbudt, var ikke længere opstigningen til forretningsmæssig succes, men snarere hengivelsen til efterlignende forbrug. Alligevel er der i sidste instans fællestræk mellem det tyske og det amerikanske fænomen, skønt de optræder i forskellige politiske sammenhænge. Som jeg udtrykte det dengang:

Men afstanden mellem det, et gennemsnitsindivid kan udrette, og de kræfter og magter, som bestemmer over dets liv og død, er blevet så uovervindelig, at identifikation med normaliteten, ja endog med den filistrøse kedsommelighed, bliver den ivrigt opsøgte mulighed for tryghed og flugt. Det giver en slags trøst for den lille mand, der er 
blevet udelukket fra Horatio Alger-drømmen, og som opgiver at finde vej gennem storpolitikkens og forretningslivets frygtindgydende vildnis, at se sine helte som en lang række almindelige fyre, som enten elsker eller afskyer whiskysjusser, cigaretter, tomatjuice, golf og sammenkomster - præcis som han selv. Han ved, hvordan han skal begå sig i forbrugs-sfæren, her kan han ikke komme ud på det dybe. Ved at indsnævre sin horisont kan han opleve den belønning, det er, at blive bekræftet $i$ sine egne fornøjelser og aversioner ved at blive delagtiggjort i de stores fornøjelser og aversioner. De store, forvirrende debatemner på politikkens og økonomiens område, de fortoner sig i oplevelsen af at være ét med de store og respektindgydende i forbrugssfaren. ${ }^{6}$

Med en tilsyneladende profetisk indsigts kraft taler Shakespeare - i Hamlets 3. akt, 2. scene - om den trussel mod individets autonomi, der udgøres af den samfundsmæssige manipulation - omend Shakespeare ikke kunne have forestillet sig, at Gyldenstjernerne i sidste ende, næsten 400 år senere, ville besejre Hamlet'erne:

Hamlet: Se, spil på denne fløjte.

Gyldenstjerne: Det kan jeg ikke, herre.

Hamlet: Jeg beder Jer.

Gyldenstjerne: Jeg forsikrer, jeg kan ikke.

Hamlet: Jeg bønfalder Jer.

Gyldenstjerne: Jcg kender ikke et eneste greb, nådige herre.

Hamlet: Det er så let som at lyve. Styr disse lufthuller med Jeres fingre og tommelen, giv dem luft med Jeres mund, så vil den udsende en såre veltalende musik. Se her, det er klapperne.

Gyldenstjerne: Men dem kan jeg ikke beherske, så der kommer velklang frem; jeg kan ikke kunsten.

Hamlet: Nå, kan I så se, hvor ussel en ting I gør mig til. I vil spille på mig! I vil lade som I kender klapperne på mig, I vil rive hjertet ud af min hemmelighed! I vil labe mig igennem fra min dybeste tone op til den øverste i mit omfang. Og der er megen musik, herlig rost i dette lille instrument; men I kan ikke få det til at sige noget - Guds blod! Tror I jeg er lettere at spille på end en fløjte? Kald mig hvad instrument I vil - I kan nok klemme på mig, men - I kan ikke spille på mig! $!^{7}$

Gyldenstjerne repræsenterer, om man vil, massekulturen, som formidler social beherskelse, som prøver at tvinge individet til lydighed og spiller på det som på et passivt, men velstemt instrument.

Det endelige resultat udtrykkes klart af den amerikanske lyriker Randall Jarrell, som siger folgende i sin bog Potry and the Age: 
Digteren lever $\mathrm{i}$ en verden, hvis aviser og blade og bøger og film og radiostationer og TV-stationer har ødelagt mange, mange menneskers evne til at forstå rigtig digtning, ja alle slags rigtig kunst... den typiske artikel i vore ugeblade indsukrer et hvilket som helst emne i den samme bevidstløse, linde strøm af sentimental »menneskelighed «. ${ }^{8}$

Jarrell kontrasterer Goethes udsagn: »Den digter, som et leksikon kan holde trit med, er ikke noget værd « med Somerset Maughams: »Den smukkeste kompliment, han nogen sinde havde modtaget, var et brev, hvori en af hans læsere sagde: »Jeg har læst Deres roman uden at være nødt til at slå et eneste ord op i en ordbog.«« Og Jarrell ender med at konstatere, at »populærlitteraturen har nu i så lang tid undladt at overlade noget som helst til fantasien, at fantasien selv er begyndt at svinde ind «. Kort sagt, fantasiens hendøen betyder også frihedens endeligt.

Jeg kan ikke sige noget endegyldigt om den ægte kunstneriske erfarings muligheder i nutiden. Kendskabet til stor kunst er utvivlsomt vokset, men kendskab uden den xgte erfaring, der er funderet $\mathrm{i}$ kritisk åbenhed, tjener kun til at understøtte systemet. Kendskab og erfaring udelukker hinanden. Jeg nærer stærk bekymring for den æstetiske erfarings muligheder forstået som frihedsbevidsthed i nutidens verden. Mere kan jeg ikke sige. Hvad jeg her har prøvet at videregive har måske ikke så meget været et resumé af mit arbejde inden for litteratursociologien, som det har været et kapitel af en måske lige lovligt anmassende intellektuel selvbiografi - en selvbiografi, som imidlertid uden falsk beskedenhed er sig områdets marginale placering bevidst. Som intellektuel er det vitterligt muligt, og måske ønskeligt, at leve i periferien. Og det har litteratursociologien givet mig udmærkede betingelser for!

Oversat af Soren Schou

Først holdt som foredrag sommeren 1981 ved Freie Universität i Berlin og Max Planck-Instituttet i Starnberg. Oversættelsen er baseret på den trykte udgave i Critical Inquiry, Autumn 1987, vol. 14, No. 1. (Chicago).

\section{Noter:}

1. Jvf. Leo Lowenthal: Schriften. Das bürgerliche Bewusstsein in der Literatur, 2:301 ff. (Frankfurt, 1981).

2. Walter Pater: The Renaissance: Studies in Art and Poetry, pp. $251-52$ (London, 1912).

3. Lowenthal: Literature and the Image of Man, pp. 42-45 (Boston, 1957). 
4. G.W.F. Hegel: Vorlesungen über die Ästhetik II, pp. 217-18. "Werke in zwanzig Bänden« vol. 14 (Frankfurt a.M. 1970).

5. Stendhal: Lucien Leuwen. Tome Premier, p. 104. "Oeuvres Complètes, „Tome 9 (GenèveParis, 1986).

6. Lowenthal: Biographies in Popular Magazines. I: »Radio Research 1942-43«, ed. P. F. Lazarsfeld et al., pp. 547-48 (New York, 1944).

7. William Shakespeare: Hamlet, Prins af Danmark. I: V. Osterbergs oversættelse: »Dramatiske Værker«, p. 288 (København, 1958).

8. Randall Jarrell: Poetry and the Age, p. 18 (New York, 1957). 